\title{
KEWENANGAN CAMAT DALAM PEMBINAAN ADMINISTRASI DESA (STUDI DI KANTOR CAMAT SEI KEPAYANG BARAT KABUPATEN ASAHAN)
}

\author{
Asriani Sitorus ${ }^{1)}$, Rahmat ${ }^{2)}$ \\ 1) Fakultas Hukum Universitas Asahan \\ 2) Fakultas Hukum Universitas Asahan \\ email: : rahmadhidayah2585@gmail.com
}

\begin{abstract}
ABSTRAK
Kecamatan Sei Kepayang Barat adalah pembagian wilayah administratif di Indonesia diwilayah Kabupaten Asahan sehingga dalam urusan otonomi daerah sebagian tugasnya dilimpahkan ke Kecamatan dan Camat mendapat wewenang untuk melakukan pengawasan dan pembinaan terhadap Pemerintah Desa karena Bupati adalah wakil Negara di tingkat Kabupaten. Mengingat kompleksnya aspekaspek atau bidang yang hendak dibangun ditingkat pemerintahan terendah tersebut, maka salah satu aspek yang terlebih dahulu perlu dibangun adalah peningkatan kemampuan aparat pemerintah desa dalam pelaksanaan tugas-tugas administrasi pemerintahan, disamping memperkuat partisipasi masyarakat dan kelembagaannya serta aspek-aspek lainnya.
\end{abstract}

Kata kunci: Kewenangan, Camat, Dalam, Pembinaan, Administrasi.

\section{ABSTRACT}

Sei Kepayang Barat Sub-district is the division of administrative areas in Indonesia in the Asahan Regency so that in matters of regional autonomy part of its duties are delegated to the District and the Camat is authorized to supervise and foster the Village Government because the Regent is the State representative at the Regency level. Given the complexity of the aspects or fields to be built at the lowest level of government, one aspect that needs to be developed first is to increase the capacity of village government officials in carrying out government administrative tasks, in addition to strengthening community participation and institutions as well as other aspects.

Keywords: Authority, Head of Sub-District, Inside, Development, Administration. 


\section{PENDAHULUAN}

Pelayanan administrasi kepada masyarakat dapat dikategorikan

efektif apabila masyarakat mendapatkan kemudahan pelayanan dengan prosedur yang singkat, biaya murah, cepat, tepat dan memuaskan.

Keberhasilan meningkatkan efektivitas pelayanan Umum ditentukan oleh faktor kemampuan pemerintah dalam meningkatkan disiplin kerja aparat pelayanan.

\section{Dalam Undang-Undang}

Nomor 32 Tahun 2006 tentang Administrasi Desa pasal 6 ayat 1

dikatakan

Pemerintah

Kabupaten/Kota dan Camat wajib membina dan mengawasi Pelaksanaan Administrasi Desa dan Pembinaan dan Pengawasan Camat sebagaimana dimaksud pada ayat (1) meliputi:

1. Memfasilitasi

Administrasi Desa;

2. Melakukan pengawasan

Administrasi Desa;

3. Memberikan bimbingan, supervisi dan konsultasi Pelaksanaan Administrasi Desa;

Hal diatas diperkuat dalam Peraturan Pemerintah Nomor 19 tahun 2008 tentang Kecamatan pasal 21 mengenai salah satu tugas camat adalah membina penyelenggaraan

pemerintahan desa melakukan pembinaan dan pengawasan tertib administrasi desa dan atau kelurahan. Dalam Peraturan Pemerintah Nomor 19 tahun 2008 tentang Kecamatan disebutkan Camat atau sebutan lain adalah pemimpin dan koordinator penyelenggaraan pemerintahan di wilayah kerja kecamatan yang dalam pelaksanaan tugasnya memperoleh pelimpahan

kewenangan pemerintahan dari Bupati/Walikota untuk menangani sebagian urusan

otonomi daerah, dan menyelenggarakan tugas umum pemerintahan.

Berdasarkan penjelasan diatas, jelas camat merupakan seorang pemimpin yang diberikan amanat

dalam menjalankan proses pemerintahan di suatu wilayah kecamatan dibawahi oleh bupati/ walikota serta memiliki wewenang yang diatur dalam undang- undang pemerintahan daerah. Peran pemerintah kecamatan sangat berpengaruh terhadap kualitas pelayanan masyarakat, camat diembankan tugas untuk membina dan mengawasi pemerintah desa/kelurahan demi terciptanya suatu pelayanan masyarakat yang maksimal. Penjelasan undang-undang tersebut selaras dengan tuntutan rakyat yang menghendaki suatu penyelenggaraan pemerintah yang

bersih dan berwibawa serta berwawasan pelayanan kepada masyarakat. Akan tetapi pada

kenyataannya masih terdapat beberapa kasus yang kurang memperhatikan bagaimana memberikan pelayanan yang baik kepada masyarakat. Hal ini dapat dilihat pada karakter birokrasi yang belum sesuai harapan di wilayahnya.

Bidang pemerintahan, aparat pemerintah diarahkan untuk menciptakan aparatur yang lebih efektif, efisien, bersih dan berwibawa serta mampu melaksanakan seluruh tugas umum pemerintah dengan sebaik-baiknya dengan dilandasi semangat dan sikap pengabdian kepada masyarakat, bangsa dan Negara. Efektivitas merupakan salah 


\section{Volume 22 No. 2, AGUSTUS 2021 ISSN 2686-5750 (ONLINE) \\ ISSN 1411-0717 (CETAK)}

satu ukuran dari pelaksanaan pekerjaan (performance). Untuk mengukur efektivitas organisasi akan sangat tergantung dari bagaimana organisasi itu mencapai tujuannya, seperti yang dikatakan oleh Handoko efektifitas adalah kemampuan untuk memilih tujuan yang tepat atau peralatan yang untuk mencapai tujuan yang telah ditetapkan. ${ }^{1}$ Dan untuk mengukur efektivitas suatu organisasi menurut Hari Lubis ada 3 pendekatan yakni pendekatan sumber, pendekatan proses dan pendekatan sasaran, berdasarkan hal inilah penulis akan melihat bagaimana efektivitas organisasi kecamatan Siau Barat dalam pembinaan administrasi desa namun dalam penelitian ini hanya menggunakan dua pendekatan saja yakni pendekatan sumber dan proses. ${ }^{2}$ Undang-Undang No. 6 Tahun 2014 tentang Desa membuka kesempatan bagi pemerintah desa untuk merealisasikan kebutuhan masyarakatnya. Kecamatan sebagai bagian dari pemerintah kabupaten yang selama ini menjalankan mandat otonomi daerah, tentunya tidak bisa lepas dari mekanisme pelaksanaan

UU Desa ini. Sayangnya, pelibatan kecamatan belum diatur secara memadai. Peran kecamatan masih perlu diperkuat mengingat kapasitas pemerintah desa yang beragam selain kondisi geografis dan topografis di Indonesia yang bervariasi Peran Kecamatan belum terperinci telah terdapat beberapa regulasi yang mengatur peran kecamatan dalam tata

\footnotetext{
1 Hani Handoko, Manajemen Personalia Dan Sumber Daya Manusia (Jakarta: PT Rafika Aditam, 1999).hlm,5.

2 Lubis \& Husain., Efektivitas Pelayanan Publik, (Jakarta: Pustaka Binaman Presindo, 1987).
}

kelola pemerintahan desa. Peraturan Pemerintah (PP) No. 19 Tahun 2008, ${ }^{3}$ bahkan secara khusus menjabarkan fungsi dan wewenang pemerintahan kecamatan sebagai tindak lanjut dari Undang-Undang No. 23 Tahun 2014 tentang Pemerintahan Daerah, belum dilengkapi dengan regulasi terkait peran kecamatan secara terperinci. ${ }^{4}$ Undang-Undang Desa juga hanya menyebutkan peran camat secara eksplisit dalam pengangkatan pejabat desa, sementara peran dalam pembinaan dan pengawasan hanya ketika dimandatkan. "Jadi, Peraturan Desa tersebut sangat penting keberadaannya di dalam membangun dan mengurus desa". 5 Pada Peraturan Pemerintah 43 Tahun 2014 ada penjelasan tentang tugas pembinaan dan pengawasan desa. Namun, penjelasan itu masih kurang spesifik

karena hanya disebutkan memfasilitasi dan mengoordinasikan berbagai tugas dan tanggung jawab desa. $^{6}$

Pemerintah kecamatan merupakan tingkat pemerintahan yang mempunyai peranan penting dalam pelaksanaan pelayanan terhadap masyarakat, hal ini yang kemudian menjadikan Camat sebagai ujung tombak dalam pelaksanaan tugas-tugas umum pemerintahan serta sebagian urusan otonomi yang

\footnotetext{
${ }^{3}$ Peraturan Pemerintah No. 19 Tahun 2008 Tentang Kecamatan.

4 Undang-Undang No. 23 Tahun 2014 Tentang Pemerintahan Daerah.

5 Elita Wihajar Sari et al., "Jurnal Tectum LPPM Universitas Asahan Edisi Vol. 2, No. 1 November 2020 1" 2, no. 1 (2020): $1-8$.

6 Peraturan Pemerintah No. 43 Tahun 2014 Tentang Peraturan Pelaksanaan Undang-Undang Nomor 6 Tahun 2014 Tentang Desa.
} 
dilimpahkan oleh Bupati/Walikota untuk dilaksanakan dalam wilayah kecamatan. Namun, tugas tersebut tidak dengan serta merta memposisikan Camat sebagai kepala wilayah seperti pada waktu lalu. Camat berkedudukan dibawah dan bertanggungjawab kepada Bupati/Walikota melalui sekretaris daerah, tugas-tugas umum pemerintahan yang diselenggarakan oleh Camat, meliputi :

1. Mengoordinasikan kegiatan pemberdayaan masyarakat;

2. Mengoordinasikan upaya penyelenggaraan ketentraman dan ketertiban umum;

3. Mengkoordinasikan penerapan dan penegakan peraturan perundangundangan;

4. Mengoordinasikan pemeliharaan prasarana dan fasilitas pelayanan umum;

5. Mengoordinasikan penyelenggaraan kegiatan pemerintahan di tingkat kecamatan;

6. Membina penyelenggaraan pemerintahan desa dan/atau kelurahan, dan;

7. Melaksanakan pelayanan masyarakat yang menjadi ruang lingkup tugasnya dan/atau yang belum dapat dilaksanakan pemerintahan desa/kelurahan. ${ }^{7}$

7 Taliziduhu Ndraha, DimensiDimensi Pemerintahan Desa (Jakarta: PT Bumi Aksara, 1991).hlm,4.
Selain melaksanakan tugastugas umum pemerintahan Camat juga melaksanakan kewenangan pemerintahan yang dilimpahkan oleh pemerintahan di atasnya untuk menangani sebagian urusan otonomi daerah, yang meliputi aspek Perizinan, rekomendasi, koordinasi, pembinaan, pengawasan, fasilitasi, penetapan, penyelenggaraan, kewenangan lain yang dilimpahkan. Pelimpahan sebagian wewenang ini dilakukan berdasarkan kriteria ekternalitas dan efisiensi. Eksternalitas yang dimaksud adalah adalah kriteria pelimpahan urusan pemerintahan dengan memperhatikan dampak yang timbul sebagai akibat dari penyelenggaraan suatu urusan pemerintahan. Apabila dampak yang ditimbulkan bersifat internal kecamatan, maka urusan pemerintahan tersebut menjadi kewenangan camat. Sedangkan yang dimaksud dengan efisiensi adalah

kriteria pelimpahan urusan pemerintahan dengan memperhatikan daya guna tertinggi yang dapat diperoleh dari penyelenggaraan suatu urusan pemerintahan dilingkup kecamatan. Apabila urusan pemerintahan lebih berdayaguna ditangani oleh kecamatan, maka urusan tersebut menjadi kewenangan

camat Pemerintah kecamatan merupakan tingkat pemerintahan yang mempunyai peranan penting dalam pelaksanaan pelayanan terhadap masyarakat, hal ini yang kemudian menjadikan Camat sebagai ujung tombak dalam pelaksanaan tugas-tugas umum pemerintahan serta sebagian urusan otonomi yang dilimpahkan oleh Bupati/Walikota 
untuk dilaksanakan dalam wilayah kecamatan. $^{8}$

Wilayah Negara Kesatuan Republik Indonesia dibagi dalam daerah-daerah provinsi. Daerah provinsi itu dibagi lagi atas daerah kabupaten dan daerah kota yang mana bersifat otonom. Setiap daerah dipimpin oleh kepalah pemerintah daerah yang disebut kepala daerah. Kepala pemerintah daerah pada tingkat kabupaten disebut Bupati.

Penyelenggaraan pemerintah ditingkat kabupaten dipimpin oleh seorang Bupati yang dibantu seorang Wakil Bupati dalam kedudukannya tersebut. Pada dasarnya Bupati memiliki tugas dan wewenang memimpin penyelenggaraan daerah

berdasarkan kebijakan yang diterapkan bersama DPRD kabupaten. Pelaksaan tugas pemerintah daerah dijalankan oleh perangkat daerah yang terdiri atas Sekretariat Daerah, Sekretariat DPRD, Dinas Daerah, Lembaga Teknis Daerah, Kecamatan, dan Kelurahan/Desa. Kecamatan dibentuk diwilayah Kabupaten/Kota yang berpedoman pada Peraturan Pemerintah. Kecamatan dipimpin

oleh seorang Camat dalam pelaksanaan tugasnya memperoleh pelimpahan sebagian wewenang Bupati atau Wali Kota untuk menangani sebagian urusan otonomi daerah.

Kecamatan Sei Kepayang Barat adalah pembagian wilayah administratif di Indonesia diwilayah Kabupaten Asahan sehingga dalam urusan otonomi daerah sebagian tugasnya dilimpahkan ke Kecamatan

${ }^{8}$ Sadu Wasistiono, MS. M.Irawan Tahir,Si, Prospek Pengembangan Desa (Bandung: CV Fokus Media, 2007).hlm,35. dan Camat mendapat wewenang untuk melakukan pengawasan dan pembinaan terhadap Pemerintah Desa karena Bupati adalah wakil Negara di tingkat Kabupaten. "Seiring dengan adanya suatu prinsip penyelenggaraan otonomi daerah, maka harus berorientasi pada peningkatan kesejahteraan masyarakat". 9

Mengingat kompleksnya aspek-aspek atau bidang yang hendak dibangun ditingkat pemerintahan terendah tersebut, maka salah satu aspek yang terlebih dahulu perlu dibangun adalah peningkatan kemampuan aparat pemerintah desa dalam pelaksanaan tugas-tugas administrasi pemerintahan, disamping memperkuat partisipasi masyarakat dan kelembagaannya serta aspekaspek lainnya.

Hal tersebut sangat penting, karena pemerintah desa beserta

aparatnya adalah sebagai administrator penyelenggara utama aktifitas pemerintahan, pembangunan dan kemasyarakatan maupun sebagai pembina ketentraman dan ketertiban di wilayah kekuasaannya. Karena itu, peranan mereka demikian penting dan banyak menentukan maju mundurnya suatu unit pemerintahan. Oleh sebab itu diperlukan aparat desa yang benarbenar mampu dan dapat bekerjasama dalam pelaksanaan tugas yang menjadi tanggung jawabnya.

Keberadaan aparat desa yang juga diserahi tugas dibidang administrasi, menduduki posisi yang sangat penting karena sebagai organ

9 Zaid Afif Sunarti, Abdul Gani, "Penyelenggaraan Pemerintah Kecamatan Ditinjau Dari Uu No. 23 Tahun 2014 Tentang Pemerintah Daerah," Jurnal Pionir LPPM Universitas Asahan Vol. 5 N0.4 Juli-Desember 2019 5, no. 23 (2019): 343-348. 
pemerintahan yang paling bawah mengetahui sacara pasti segala kondisi dan permasalahan yang ada di wilayahnya, maka input pada

pemerintah kecamatan yang menyangkut berbagai keterangan dan informasi sangatlah dibutuhkan dalam pengambilan kebijaksanaan daerah maupun nasional untuk kebutuhan pembangunan secara menyeluruh. Dengan demikian kepala desa dalam pelaksanaan tugasnya sehari-hari, terutama yang berbuhungan dengan penyajian data dan informasi yang dibutuhkan, semakin dituntut adanya kerja keras dan kemampuan yang optimal guna memperlancar pelaksanaan tugas pemerintahan. ${ }^{10}$ Keberadaan aparat desa yang juga diserahi tugas dibidang administrasi, menduduki posisi yang sangat penting karena sebagai organ pemerintahan yang paling bawah mengetahui sacara pasti segala kondisi dan permasalahan yang ada di wilayahnya, maka input pada pemerintah kecamatan yang menyangkut berbagai keterangan dan informasi sangatlah dibutuhkan dalam pengambilan kebijaksanaan daerah maupun nasional untuk kebutuhan pembangunan secara menyeluruh. Dengan demikian kepala desa dalam pelaksanaan tugasnya sehari-hari, terutama yang berbuhungan dengan penyajian data dan informasi yang dibutuhkan, semakin dituntut adanya kerja keras dan kemampuan yang optimal guna memperlancar pelaksanaan tugas pemerintahan.

Berangkat dari pemikiran tersebut, dikaitkan dengan kondisi rill sementara Aparat Pemerintah Kecamatan Sei Kepayang Barat,

${ }^{10}$ Rusadi Kantaprawira, Hukum Dan Kekuasaan (Yogyakarta, 1998).hlm,37-38.
Kabupaten Asahan sebagai tempat penelitian yang direncanakan ini, menurut pengamatan awal penulis bahwa kemampuan Perangkat Desa dalam pelaksanaan tugas terutama dalam menyiapkan bahan dan informasi yang dibutuhkan untuk kepentingan perencanaan pembangunan, hasilnya masih minim atau belum terlaksana secara optimal. Hal ini terbukti dari kineja pemerintah desa yang tidak terlaksana dengan

baik dan konsisten dalam menyediakan informasi yang dibutuhkan.

Belum maksimalnya kinerja pemerintah desa secara baik sebagaimana tersebut diatas, maka hal itu terjadi karena adanya pengaruh berbagai faktor, antara lain terutama faktor kemampuan sumber daya aparat desa sebagai penyelenggara yang belum optimal. Dalam konteks penyelenggaraan pemerintahan desa yang terpenting adalah bagaimana pemerintahan desa mampu meningkatkan kesejahteraan rakyatnya, mampu memberikan pelayanan kepada masyarakat desa, dan mampu meningkatkan daya saing desanya. Hal tersebut hanya mungkin terwujud apabila urusan yang menjadi kewenangan desa dapat terlaksana dengan baik. Namun yang terjadi di lapangan terdapat berbagai permasalahan yang langsung maupun tidak langsung menghambat pelaksanaan urusan- urusan pemerintahan tersebut.

Upaya membentuk karakter aparatur negara yang unggul dan

berkualitas serta mampu mengembangkan potensi kepribadian khususnya dalam menanamkan nilai dan prinsip moral yang baik dalam melaksanakan tugas dan fungsi selaku 
aparatur pemerintahan desa. Praktek penyelenggaraan pemerintahan desa di Indonesia memang seringkali mengalami persoalan-persoalan yang timbul terkait dengan hubungan tersebut, termasuk tentang sikap disiplin pemerintah desa dalam menjalankan tugas dan fungsi. Untuk mencapai hasil yang baik dalam menjalakan tugas dan fungsi, perlu adanya disiplin yang baik dari para anggota perangkat desa yang bersangkutan. $^{11}$

Disiplin yang baik mencerminkan besarnya rasa tanggung jawab seseorang terhadap tugas- tugas yang diberikan kepadanya. Disamping itu disiplin

dapat dijadikan alat untuk membangun kepribadian perangkat desa dimana apabila lingkungan kerjanya baik maka akan berdampak positif bagi pribadi perangkat desa tersebut. Realita yang terjadi di lapangan marak terdapat kasus-kasus yang menunjukkan perangkat desa belum menjalankan tugas dan fungsi secara disiplin. Salah satunya yaitu kinerja perangkat desa yang kurang maksimal karena sering melakukan aktivitas lain yang tidak sesuai dengan tugas dan fungsi, kedatangan ke kantor desa sering terlambat, pemerintah desa kurang aktif di tempat kerja, sehingga keadaan kantor kadang-kadang tutup karena tidak adanya pegawai kantor desa yang turun kerja. Terkadang jika ada yang ingin berurusan harus mencari perangkat desa di rumah mereka sendiri dan ada juga yang tidak ada di tempat karena sebagian dari

11 Trijono, Lambang Pembangunan Sebagai Perdamaian (Jakarta: Yayasan Obor Indonesia, 2007).hlm,6. perangkat desa mempunyai pekerjaan sampingan seperti petani atau pun berkerja dengan swasta sebagai kuli long boad. Sehingga peneliti menilai aparat pemerintah desa masih rendah dalam kedisiplinan kerja karena kondisi pegawai yang jarang berada di tempat kerja ataupun berada di Desa.

Seperti yang kita ketahui bahwa disiplin merupakan faktor pengikat dalam suatu pekerjaan yang memksa pegawai untuk mentaati peraturan serta prosedurnya yang berlaku. Disiplin merupakan perasaan taat dan patuh terhadap nilai-nilai yang dipercaya merupakan tanggung jawabnya. Secara konsep hal disiplin telah merujuk pada sikap yang selalu taat kepada aturan, norma dan prinsip-prinsip tertentu. Disiplin juga kemampuan untuk mengendalikan diri dengan tenang dan tetap taat walaupun dalam situasi yang sangat menekan sekalipun, disiplin mengikuti tata tertib peraturan yang harus ditaati (ketaatan). Dengan demikian jelaslah bahwa suatu

kedisiplinan merupakan kunci terwujudnya tujuan suatu yang ingin dicapai, karena dengan terwujudnya kedisiplinan yang baik berarti pegawai sadar dan menjalankan tugas dan fungsinya dengan baik. ${ }^{12}$

Kapasitas yang masih rendah merupakan bagian dari permasalahan yang ditunjukkan di lapangan. Diantaranya masih belum optimalnya aspek kelembagaan, sumberdaya manusia, maupun manajemen pemerintahan Desa.

Arenawati, Administrasi Pemerintahan Daerah, Sejarah, Konsep Dan Penatalaksanaan Di Indonesia, (Yogyakarta: Graha Ilmu, 2014).hlm,23. 
Dari uraian latar belakang tersebut, maka dalam penulisan ini, penulis mengambil judul "KEWENANGAN CAMAT DALAM PEMBINAAN ADMINISTRASI DESA (STUDI DI KANTOR CAMAT SEI KEPAYANG KABUPATEN ASAHAN)"

BARAT

\section{METODE PENELITIAN Metode}

di sini diartikan

sebagai suatu cara atau teknis yang dilakukan dalam proses penelitian. Sedangkan penelitian itu sendiri diartikan sebagai upaya dalam bidang ilmu pengetahuan yang dijalankan untuk memperoleh fakta-fakta dan prinsip-prinsip dengan sabar, hati-hati dan sistematis untuk mewujudkan kebenaran. $^{13}$

Metode pada hakikatnya merupakan prosedur dalam memecahkan suatu masalah dan untuk mendapatkan pengetahuan secara ilmiah, kerja seorang ilmuwan akan berbeda dengan kerja seorang awam.

\begin{tabular}{rrr}
\multicolumn{1}{r}{ "Seorang } & ilmuwan & selalu \\
menempatkan & logika & serta \\
menghindarkan & diri & dari
\end{tabular}
pertimbangan subyektif. Sebaliknya bagi awam, kerja memecahkan masalah lebih dilandasi oleh campuran pandangan perorangan ataupun dengan apa yang dianggap sebagai masuk akal oleh banyak orang. "14

Untuk dapat merampungkan penyajian skripsi ini agar dapat

13 Mardalis, Metode Penelitian (Suatu Pendekatan Proposal), (Jakarta: Bumi Aksara, 2004).hlm, 24.

14 Bambang Sunggono, Metodologi Penelitian Hukum, ed. PT Raja Grafindo Persada (Jakarta, 2004).hlm,43. memenuhi kriteria sebagai tulisan ilmiah diperlukan data yang relevan dengan skripsi ini. Dalam upaya pengumpulan data yang diperlukan itu, maka penulis menerapkan metode pengumpulan data sebagai berikut:

\section{Jenis Penelitian}

Jenis penelitian yang digunakan adalah penelitian hukum Empiris, dimaksudkan hukum ini dikonsepkan sebagai suatu gejala empiris yang dapat diamati dalam kehidupan nyata. ${ }^{15}$ Penelitian juga dilakukan secara yuridis yang artinya penelitian yang dilakukan dimulai dari pendekatan peermasalahan dari segi hukum yakni berdasarkan peraturan perundang-undangan yang berlaku, pendapat dari para sarjana atau doktrin. Sementara penelitian yang dilakukan secara empiris ini dilakukan dengan melihat fakta-fakta yang terjadi di masyarakat berkaitan dengan penulisan ini. Sehingga objek dari penelitian adalah hukum sebagai gejala social didalam perilaku masyarakat.

\section{Lokasi Penelitian}

Untuk memperoleh data dan informasi yang dibutuhkan yang berkaitan dengan permasalahan dan pembahasan, dengan melakukan penelitian dengan memilih penelitian di Kantor Camat Sei Kepayang Barat Kabupaten Asahan.

\section{Sumber Data}

Jenis data yang digunakan dalam penelitian hukum ini adalah data sekunder, yaitu data pustaka yang mencakup dokumen-dokumen resmi, buku-buku hasil penelitian yang berwujud laporan, buku harian

\section{Peter Mahmud Marzuki,}

Penelitian Hukum, Edisi Pertama, Cet. VII (Jakarta: Kencana Prenada, 2011).hlm,119. 
dan buku-buku yang berkaitan dengan pokok bahasan yang dikaji oleh peneliti. Sumber data yang digunakan dalam penelitian ini ialah sumber data sekunder. Soerjono Soekanto menyebutkan data sekunder tersebut mencakup:

a. Bahan hukum primer, yaitu data yang di peroleh langsung dari lokasi penelitian yaitu di Kantor Camat Sei Kepayang Barat Kabupaten Asahan dan Sumber data primer ini adalah hasil dari wawancara tarhadap pihak-pihak yang mengetahui atau menguasai permasalahan.

b. Bahan hukum sekunder, yaitu bahan yang memberikan penjelasan mengenai bahan hukum primer. Bahan hukum sekunder berupa semua publikasi tentang hukum yang merupakan dokumen-dokumen resmi.

Publikasi tentang hukum meliputi buku-buku yang terkait dengan masalah yang dikaji, hasil-hasil penelitian, hasil karya dari kalangan hukum, jurnaljurnal hukum.

c. Bahan hukum tersier, yaitu bahan yang memberikan petunjuk maupun penjelasan terhadap bahan hukum primer dan bahan hukum sekunder berupa kamus hukum atau kamus bahasa Indonesia untuk menjelaskan maksud atau pengertian istilah-istilah

$$
\text { yang } \text { diartikan. }^{\text {sulit untuk }}
$$

4. Teknik Pengumpulan Data

Teknik pengumpulan data yang dipergunakan oleh peneliti dalam penelitian ini adalah studi kepustakaan atau studi dokumen. Teknik ini merupakan teknik pengumpulan data dengan mempelajari, membaca, dan mencatat buku-buku, literatur, catatan-catatan, peraturan perundang-undangan, serta artikel-artikel penting dari media internet yang erat kaitannya dengan pokok-pokok masalah yang digunakan untuk menyusun penulisan hukum ini yang kemudian dikategorikan menurut pengelompokan yang tepat.

\section{Analisis Data}

Penelitian ini menggunakan metode analisis data dengan logika deduktif. Menurut Johny Ibrahim yang mengutip pendapat Benard Arief Shiharta, logika deduktif merupakan suatu teknik untuk menarik kesimpulan dari hal yang bersifat umum menjadi kasus yang bersifat individual, ${ }^{17}$ Sedangkan Philiphus M. Hadjon menjelaskan metode deduksi sebagaimana silogisme yang diajarkan oleh Aristoteles. Penggunaan metode deduksi berpangkal dari pengajuan premis major (pernyataan bersifat umum). Kemudian diajukan premis minor (bersifat khusus), dari kedua premis itu kemudian ditarik suatu kesimpulan atau Conclusion. Jadi yang dimaksud dengan pengolahan bahan hukum

\footnotetext{
16 Soerjono Soekanto, Pengantar

Penelitian Hukum (Jakarta: Penerbit Universitas Indonesia, 2016).hlm,52.

17 Jonny Ibrahim, Teori Dan Metode Penelitian Hukum Normatif, (Surabaya: Bayu Media Publishing.).hlm,249.
} 
dengan cara deduktif adalah menjelaskan sesuatu dari hal-hal yang sifatnya umum, selanjutnya menarik kesimpulan dari hal itu yang sifatnya lebih khusus.

Dalam penulisan ini, data diperoleh dengan melakukan inventarisasi sekaligus mengkaji dari penelitian studi kepustakaan, aturan perundang-undangan beserta dokumen-dokumen yang dapat membantu menafsirkan norma tersebut dalam mengumpulkan data, kemudian data itu diolah dan

dianalisis untuk menjawab permasalahan yang diteliti. Tahap terakhir adalah menarik kesimpulan dari data yang telah diolah, sehingga pada akhirnya dapat diketahui mengenai kewenangan camat dalam pembinaan administrasi desa.

\section{HASIL DAN PEMBAHASAN Tanggung Jawab Camat Terhadap Pemerintah Desa Dalam Pembinaan Administrasi Desa Kecamatan Sei Kepayang Barat}

Pembinaan organisasi

bermaksud untuk mengembangkan individu- individu, kelompok, dan atau seluruh sistem dalam organisasi secara keseluruhan. pembinaan dapat diartikan sebagai upaya memelihara membawa suatu keadaan yang seharusnya terjadi atau menjaga keadaan sebagai mana mestinya.

Pembinaan bertujuan untuk meningkatkan kemampuan, semangat dalam melakukan pekerjaan dan kedisiplinan dalam menjalankan tugas yang menjadi tanggung jawab dan tidak mempunyai sikap dan tindakan yang bertantangan dengan pekerjaan maka perlu dilakukan peningkatan kapasitas Aparatur Pemerintahan guna meningkatkan kompetensi, profesionalisme dan kemampuan manajemen aparat pemerintah sesuai dengan kebutuhan guna mendukung penyelenggaraan pemerintah, pengelolaan pembangunan dan fasilitas pemberdayaan masyarakat. Pemerintahan desa sebagai penggerak atau pelaksanaan kegiatan-kegiatan pemerintahan dalam mencapai berbagai keberhasilan pembangunan. Camat secara umum memimpin penyelenggaraan pemerintah, baik pemerintahan di desa maupun pemerintahan kelurahan, tugas pembangunan dan kehidupan masyarakat serta penyelenggaraan koordinasi atas instansi vertical.

Sebagai pejabat Pembina pemerintahan desa seharusnya camat mempunyai program pembinaan supaya pembinaan yang dilakukan terarah sesuai dengan maksud dan tujuan pemerintahan desa, agar pembinaan bisa berjalan dengan baik maka program pembinaan yang harus dilakukan adalah sebagai berikut ${ }^{18}$

1. Bimbingan;

2. Supervisi;

3. Konsultasi;

4. Pemberian pedoman;

5. Fasilitasi.

Seperti yang telah dipaparkan sebelumnya bahwasannya yang memberikan pembinaan itu adalah camat dan stafnya sedangkan yang dibina itu adalan aparat pemerintahan desa. Adapun hasil penelitian penulis tentang peranan camat dalam membina administrasi pemerintahan desa di Kecamatan Mempura

18 Hasil Wawancara Pada Dengan Bapak Rahmad Hidayat Rambe, S.I.P., Camat Sei Kepayang Barat Pada 23 Nopember 2020. 
Kabupaten Siak berdasarkan pada indikatornya yaitu:

1. Bimbingan

Bimbinganmerupakan

bantuan yang diberikan individu (peserta didik) agar dengan potensi yang dimiliki mampu mengembangkan diri secara optimal.

Dengan adanya bimbingan diharapkan dapat meningkatkan kualitas Sumber Daya Manusia yang ada serta bisa meningkatkan disiplin dan rasa tanggung jawab terhadap sebuah pekerjaan agar tujuan bisa tercapai seperti yang diinginkan. Untuk melakukan bimbingan itu dapat dilakukan dengan beberapa langkah:

a. Memberikan Petunjuk

Memberikanpetunjukdalam

pembinaan penyelenggaraan pemerintahan desa terhadap aparatur desa sangatlah perlu, karena masih banyaknya tugas-tugas yang belum mereka pahami dalam menertibkan administrasi pemerintahan desa.

Pemberian petunjuk dalam penyelenggaraan tugas pemerintah desa memang menjadi tugas pemerintah kecamatan yang mana petunjuk tidak hanya diberikan oleh camat melainkan semua staf yang ada dipemerintah kecamatan yang dianggap memahami permasalahan atau penyelenggaraan tugas pemerintah desa bisa melalui Sekcam ataupun Kepala Seksi yang ada.

b. Memberikan pengarahan Pengarahan sangat dibutuhkan oleh aparat desaterhadap penyelenggaraan tugas Pemerintah Desa karena dengan pengarahan bisa melaksanankan tugas lebih baik lagi

c. Adanya Pelatihan

Pelatihan sangat menunjang kinerja dan prestasi kerja karena dengan pelatihan akan mendapatkan pendidikan sehingga meningkatkan kualitas sumber daya manusia yang ada dipemerintahan desa untuk mengetahui tata cara pelaksanaan penyelenggaraan pemerintah desa dan arti pentingnya penataan tertib administrasi desa tersebut.

d. Adanya Rapat kerja

Dengan diadakan rapat kerja maka permasalahan yang dihadapi oleh masing-masing penyelenggaraan pemerintah desa bisa dikemukakan dan dipecahkan bersama-sama, dan bisa menunjang perbaikan kinerja aparat desa satu dengan yang lainnya. Dengan mengadakan rapat kerja dan mengumpulkan aparat desa sebanarnya sangat membantu penyelenggaraan pemerintah desa, dimana dengan itu bisa melakukan perbaikan-perbaikan, bisa saling bertukar pikiran dan menilai kinerja dari masing-masing desa agar pekerjaan lebih efektif dan efisien.

\section{e. Melakukan Evaluasi}

Melakukan Evaluasi "Penilaian" terhadap kinerja pemerintah desa juga bisa meningkatkan semangat kerja, dengan adanya penilaian diharapkan membimbing agar termotivasi untuk melaksanakan tugas dengan lebih baik lagi.

2. Supervise

Untuk tercapainya efektifitas pembinaan penyelenggaraan pemerintahan desa perlu diadakan suatu tindakan pengawasan terhadap penyelenggaraan administrasi pemerintahan desa, yang akan mengawasi jalannya administrasi yangakandiberikanoleh pemerintahankepadapara aparaturnya. Dalam birokrasi pemerintahan di Indonesia dikenal adanya pengawasan umum, yaitu 
pengawasan yang dilakukan oleh inspektorat dan pengawasan melekat yang dilaksanakan oleh atasan langsung masing-masing staf. Adapun sub indikator dari supevisi yang dilakukan terhadap adminisrtasi pemerintahan desa dapat dilihat pada penilaian sebagai berikut:

a. Pengawasan Langsung Pengawasan langsung yang dilakukan langsung oleh atasan memengang sangat membawa pengaruh tehadap kinerja bawahan, dengan adanya pengawasan langsung bisa meningkatkan kinerja sumber daya manusia yang ada. Pengawasan langsung sangat menunjang pelaksanaan tugas aparat desa karena peranan seorang atasan sangatlah dipatuhi oleh bawahan, sehingga dengan pengawasan langsung yang dilakukan oleh atasan sangat menentukan dan menjadikan sebuah pekaerjaan yang berdaya guna dan

berhasil guna. Karena peran pemimpin sangatlah kuat dalam penyelenggaraan pemerintah menuju terwujudnya tujuan otonomi.

b. Pengawasan Tidak Langsung Pengawasan tidak langsung juga bisa membantu tertib penataan administrasi desa, yang mana dengan pengawasan tidak langsung pihak

kecamatan bisa mengetahui perkembangan-perkembangan terhadap penyelenggaraan pemerintah desa.

Sejauh ini untuk Pengawasan tidak langsung dengan meminta

laporan kependudukan setiap bulannya sudah dilaksanakan oleh pihak kecamatan, dimana setiap desa harus menyerahkan laporan kependudukannya kepada pihak kecamatan. c. Pengawasan terhadap Kepala Desa

Dengan meminta laporan harian kerja sebenarnya sudah sedikit membantu pengawasan yang dilakukan terhadap penyelenggaraan pemerintah desa, karena sedikit banyaknya bisa mengetahui bagainama kinerja kepala desa sebagai pemimpin pemerintah desa dalam menyelenggarakan pemerintah desa.

d. Pengawasan terhadap Aparatur Desa

Pada dasarnya Pengawasan terhadap aparat desa sangatlah perlu dilakukan karena Aparat desa merupakan subjek penggerak dalam penyelenggaraan pemerintah desa dan sumber daya manusia haruslah baik,

dalam pengertian moral dan kapasitasnya karena keberhasilan pencapaian tujuan tidak terlepas dari kemampuan aparatur desa dalam melaksanakan tugasnya.

e. Melakukan pengawasan tertib administrasi pemerintahan desa

Administrasi di pemerintahan desa sangatlah vital dimana segala urusan surat menyurat, tanah, jual beli dan system prosedur dilaksanakan disana. Pengawasan sangatlah dibutuhkan dalam penertiban administrasi pemerintahan desa karena desa merupakan ujung tombak pemerintahan yang berhadapan langsung dengan masyarakat data yang terkandung didesa tidak hanya berguna bagi pembangunan desa tetapi bagi pembangunan bangsa dan menjadi tolak ukur untuk meratakan pembangunan desa karena desa

merupakan integral dari pembangunan bangsa.

\section{Konsultasi}


Konsultasi merupakan sebuah pertemuan/konvarensi untuk saling bertukar informasi dan saran. Dengan adanya konsultasi pemerintah desa bisa mengutarakan masalah-masalah yang dihadapi dalam penyelenggaraan pemerintahannya. Dengan adanya komunikasi yang baik maka proses konsultasi ini tidak akan sulit

dilaksanakan. Untuk melihat tanggapan responden mengenai konsultasi dapat dinilai melalui sub indikator yang akan dijelaskan berikut ini.

a. Pemberian Masukan

b. Menerima keluhan

c. Memberikan Penjelasan

d. Menjalin Komunikasi

e. Memberikan Solusi

4. Pemberian Pedoman Dalam menyelenggarakan sebuah tanggung jawab memang diperlukan pedoman sebagai acuan untuk melaksanakan tugas agar tidak menyimpang dari tujuan yang telah ditetapkan. Pedoman bisa berupa Buku, undang-undang, juknis dan lain-lain.

a. Memberikan Petunjuk Teknis

b. Memberikan buku-buku

c. Menjelaskan Pedoman yang diberikan

d. Manfaat Pedoman

e. Mendatangkan Tenaga Ahli

5. Fasilitasi

Fasilitasi merupakan upaya memudahkan tugas dan fungsi yang diemban kepada pemerintah desa. Untuk melihat proses fasilitasi yang dilakukan oleh camat dengan penilaian dari sub indikator akan dijelaskan pada penjelasan bidawah ini.

a. Fasilitasi Tata Administasi
b. Fasilitasi
penyusunan peraturan desa
c. Fasilitasi Kepala Desa
d. Fasilitasi kerjasama antar desa
e. Fasilitasi ketentraman dan ketertiban

\section{Hambatan-Hambatan Camat} Dalam Pelaksanaan Pembinaan Administrasi Desa Terhadap Aparat Pemerintah Desa, Kecamatan Sei Kepayang Barat, Kabupaten Asahan

Salah satu tujuan pembinaan adalah untuk menumbuhkan dan meningkatkan partisipasi aparatur pemerintah desa, hal ini berarti bahwa hasil dan pembinaan camat adalah di mana aparatur pemerintah desa/kelurahan dan masyarakat berperan serta dalam pembinaan yaitu ikut sertanya masyarakat dan aparatur pemerintah desa dalam merencanakan, menentukan, melaksanakan tujauan pembinaan dan akhirnya menikmati terwujudnya tujuan-tujuan yang telah di rencanakan. Kegiatan pembinaan camat terhadap aparatur pemerintah desa tercakup dalam konsep pembinaan yaitu camat sebagai ujung tombak dalam pelaksanaan tugastugas umum pemerintah serta sebagian urusan otonomi yang di limpahkan oleh Bupati/Walikota untuk di laksanakan dalam wilayah kecamatan.

Camat dalam menjalankan tugasnya dibantu oleh perangkat kecamatan dan bertanggung jawab kepada bupati/walikota melalui sekretaris daerah kabupaten/kota. Pertanggungjawaban camat kepada bupati/walikota melalui sekretaris daerah adalah pertanggungjawaban administratif. Pengertian melalui sekretaris daerah bukan berarti camat 
merupakan bawahan langsung sekretaris daerah, karena secara struktural camat berada langsung di bawah bupati/walikota.

Camat berperan sebagai kepala wilayah (wilayah kerja, namun tidak memiliki daerah dalam arti

daerah kewenangan), karena melaksanakan tugas umum pemerintahan di wilayah kecamatan, khususnya tugas-tugas atributif dalam bidang koordinasi pemerintahan terhadap seluruh instansi pemerintah di wilayah kecamatan, penyelenggaraan ketenteraman dan ketertiban, penegakan peraturan perundang-undangan, pembinaan penyelenggaraan pemerintahan desa dan/atau kelurahan, serta pelaksanaan tugas pemerintahan lainnya yang belum dilaksanakan oleh pemerintahan desa/kelurahan dan/atau instansi pemerintah lainnya di wilayah kecamatan. Oleh karena itu, kedudukan camat berbeda dengan kepala instansi pemerintahan lainnya di kecamatan, karena penyelenggaraan tugas instansi pemerintahan lainnya di kecamatan harus berada dalam koordinasi camat. Dalam melaksanakan pembinaan dan pengawasan terhadap perangkat

kelurahan, camat memberikan pengarahan-pengarahan yang konferhensip kepada kelurahan agar proses penyelenggaraan pemerintahan benar-benar terlaksana dengan baik

sesuai dengan peraturan dan perudang-undangan yang berlaku. Selain itu juga camat melakukan pembinaan terhadap peningkatan sumber daya manusia (SDM) di kelurahan, misalnya memberikan pelatihan dan melakukan pengawasan tentang kedisiplinan kerja perangkat desa agar mereka memiliki kemampuan yang tinggi dan disiplin kerja yang tinggi dalam rangka pelaksanaan penyelenggaraan pemerintahan di kelurahan.

Melakukan pembinaan dan pengawasan tertib administrasi pemerintahan di kelurahan merupakan tanggung jawab seorang pemimpin dalam menjalankan fungsinya sebagai pemimpin yang harus dilakukan

seorang camat dalam penyelenggaraan pemerintahan. Camat melakukan sosialisasi tentang pelaksanaan penyelenggaraan sistem atau prosedur administrasi pemerintahan tentang cara pembuatan surat dinas dan format surat resmi kepemerintahan.

Sebagaimana diatur dalam Pasal 50 Peraturan Pemerintah Nomor 18 Tahun 2016 tentang Perangkat

Daerah, Kelurahan merupakan perangkat kecamatan yang dibentuk untuk membantu atau melaksanakan sebagian tugas camat. Salah satu tugas dari lurah adalah membantu camat dalam melaksanakan kegiatan pemerintahan kelurahan. Hal yang terpenting dari fungsi pembinaan camat itu sendiri adalah adanya koordinasi serta kerja sama yang di lakukan oleh setiap lembaga atau aparat pemerintah kelurahan dengan masyarakat, sehingga setiap kebijakan-kebijakan yang di keluarkan oleh pemerintah dapat di jalankan dan di laksanakan dengan baik oleh masyarakat itu sendiri. Dengan demikian,masyarakat mampu untuk menunjang setiap programprogram dan kegiatan-kegiatan demi terciptanya suatu pembangunan yang adil dan merata di segala bidang. Sangat di harapkan agar perangkat kelurahan benar-benar harus berperan secara aktif dalam menyukseskan 
setiap agenda-agenda yang sudah di tetapkan oleh pemerintah.

Kelurahan sebagai organisasi pemerintahan yang paling dekat dan berhubungan langsung dengan masyarakat.Pemerintah Kelurahan dituntut untuk semaksimal mungkindalam memberikan pelayanan kepada masyarakat setempat. Lurah dituntut untuk profesional dan menguasai secara baik pekerjaannya melebihi rata-rata pegawai yang ada, serta memiliki komitmen moral yang tinggi atas pekerjaannya sesuai dengan kode etik profesinya sebagai pemimpin.

$$
\text { Dalam melaksanakan }
$$

tugasnya, berdasarkan wawancara penulis dengan kelurahan Sorosutan, kelurahan Giwangan dan kelurahan Pandeyan, kelurahan- kelurahan tersebut juga mengalami kendala kekurangan sumber daya manusia, dalam hal ini staf untuk melayani masyarakat sangat kurang, sehingga untuk mengatasi maslah tersebut, pegawai dari bidang lain ikut

membantu. Apabila permintaan pelayan banyak pegawai kelurahan kewalahan untuk melayani yang berdampak pada sistem pelayanan menjadi terganggu dan masyarakat yang mengantri harus menunggu lebih lama.

Kendala-kendala tersebut juga di alami oleh kecamatan. Dalam wawancara dengan Sekertaris Camat, pelaksanaan program kegiatan masih juga ditemui adanya ketidakberhasilan sehingga realisasi

kinerja, khususnya penyerapan realisasi anggaran tidak bisa mencapai $100 \%$ karena ada beberapa hambatan yang dihadapi. Penyebab ketidak berhasilan yang ada meliputi antara lain meliputi : ${ }^{19}$

1. Kualitas dan Kuantitas Sumber Daya pegawai yang belum sesuai dengan beban tugas;

2. Adanya moratorium, mutasi pegawai yang tidak diiringi penggantian personil, sementara terdapatpelimpahan kewenangan yang begitu banyak, termasuk pembangunan fisik tetapi tidak adatenaga teknis;

3. Peraturan pelaksanaan teknis yang belum jelas dan kurang koordinatif;

4. Belumoptimalnya penggunaan teknologi informasi; dan

5. Semakin tingginya tuntutan pelayanan Masyarakat.

Sedang yang masih perlu pembenahan adalah program Program Peningkatan Pelayanan Masyarakat Berbasis Kewilayahan dan Program Pemberdayaan Masyarakat Berbasis Kewilayahan karena keterbatasan SDM yang ada maka ke dua program tersebut masih mengalami sedikit

hambatan. Adanya pelimpahan kewenangan yang sedemikian banyak namun tidak diringi dengan penambahan personil bahkan banyak pengurangan personil karena adanya promosi jabatan, pensiun dan tugas belajar mengakibatkan pembuatan administrasi agak terhambat. Apalagi terdapat kepala Seksi maupun Kepala Sub Bagian yang tidak mempunyai staf sama sekali, namun harus melaksanakan tugas dan fungsi yang sedemikian banyak dengan kata lain harus merangkap fungsi jabatan lebih

${ }^{19}$ Ibid. 
dari satu atau dua jabatan. Bahkan satu orang bisa mempunyai fungsi jabatan 4 jabatan.

Kendala-kendala tersebut juga berdampak pada tugas camat untuk melakukan pembinaan ke pemerintahan kelurahan, hal karena kecamatan sudah disibukkan dengan permasalahan-permasalahan di kecamatan, sehingga untuk melakukan pembinaan ke kelurahan akan terhambat. Beberapa strategi yang di ambil oleh kecamatan untuk mengatasi permasalahan yang ada, antara lain : 20

1. Peningkatan

Kapasitas

Sumber Daya Aparatur

(Pelatihan Exelent service),

Bintek,

Pelatihan

Kepemimpinan, publick speaking bagiseluruh Pegawai

Kecamatan Sei Kepayang Barat. Pelatihan tersebut dilaksanakan dengan Anggaran pelimpahan Kewenangan kepada Camat;

2. Adanya upaya untuk memotivasi dan meningkatkan kesadaran masyarakat, terutama dalam memenuhi prosedur pelayanan;

3. Mengoptimalkan dukungan sumber daya pegawai yang ada dan memberikan kesempatankepada pegawai yang masih potensial untuk dikembangkan;

4. Memanfaatkan personil yang ada, termasuk adanya ketugasan rangkap dalam administrasi keuangan;

5. Terus mengupayakan untuk meningkatkan kesadaran akan

${ }^{20}$ Ibid. pentingnya penggunaan teknologi informasi;

6. Berupaya untuk memberikan dukungan sarana dan prasarana dalam mendukung ketugasan; dan

7. Selalu bekerjasama dan bermitra dengan lembagalembaga masyarakat yang ada Adanya koordinasi, sinergitas maupun kerjasama yang baik, antar pegawai, antar instansi maupun

lembaga yang ada dapat menghasilkan kerja sama yang baik. Selanjutnya dengan kerja sama yang baik dapat menutupi faktor hambatan yang menonjol yaitu Sumber Daya Manusia. Dengan memaksimalkan koordinasi dan kerja sama yang baik, maka kekurangan dapat tercukupi.

Berdasarkan penjabaran diatas, hambatan yang dihadapi oleh Kecamatan Sei Kepayang Barat dalam mengimplementasikan tugas dan weewenang camat dalam mengkoordinasikan pemerintahan kelurahan di Kecamatan Sei Kepayang Barat adalah Kualitas dan kuantitas sumber daya pegawai yang belum sesuai dengan beban tugas di tambah lagi adanya moratorium penerimaan pegawai dan mutasi

pegawai yang tidak diiringi penggantian personil sementara terdapat pelimpahan kewenangan yang begitu banyak sehingga kecamatan kekurangan pegawai yang berdampak pada kualitas pekerjaan yang tidak maksimal termasuk pembangunan fisik tetapi tidak adatenaga teknis. Selain itu masih ada peraturan pelaksanaan teknis yang belum jelas dan kurang koordinatif yang menyulitkan pemerintahan kecamatan untuk mentransferkan peraturan tersebut ke pihak kelurahan. 
ISSN 1411-0717 (CETAK)

Hambatan lainnya adalah belum optimalnya penggunaan teknologi informasi dan semakin tingginya tuntutan pelayanan masyarakat. ${ }^{21}$

\section{KESIMPULAN}

Dari perumusan masalah yang penulis kemukakan serta pembahasannya baik yang berdasarkan teori maupun data-data yang penulis dapatkan selama mengadakan penelitian, maka penulis mengambil kesimpulan sebagai berikut:

$$
\text { 1. Dalam Undang-Undang }
$$

Nomor 32 Tahun 2004 tentang Pemeritahan Daerah pada pasal 126 ayat (1) berbunyi:

Kecamatan dipimpin oleh Camat yang pelaksanaan tugasnya memperoleh pelimpahan bupati atau walikota untuk menangani sebagian urusanotonomi daerah.

2. Administrasi Pemerintahan Desa adalah serangkaian kegiatan yang dilakukan dalam rangka penyelenggaraan pemerintahan desa dan kepala desa untuk mencapai tujuannya itu pemerintah desa mampu mengerakkan masyarakat dalam partisipasinya dalam pembangunan dan terwujudnya demokrasi secara nyata guna meningkatkan taraf hidup masyarakat.

\section{DAFTAR PUSTAKA Buku}

${ }^{21}$ Ibid.
Arenawati.

Administrasi

Pemerintahan Daerah,

Sejarah, Konsep Dan Penatalaksanaan Di

Indonesia, . Yogyakarta:

Graha Ilmu, 2014.

Bambang Sunggono. Metodologi Penelitian Hukum. Edited by PT Raja Grafindo Persada. Jakarta, 2004.

Hani Handoko. Manajemen Personalia Dan Sumber Daya Manusia. Jakarta: PT Rafika Aditam, 1999.

Jonny Ibrahim. Teori Dan Metode Penelitian Hukum Normatif, . Surabaya: Bayu Media Publishing, n.d.

Lubis\& Husain. Efektivitas Pelayanan Publik,. Jakarta: Pustaka Binaman Presindo, 1987.

Mardalis. Metode Penelitian (Suatu Pendekatan Proposal),. Jakarta: Bumi Aksara, 2004.

Peter Mahmud Marzuki. Penelitian Hukum, Edisi Pertama, Cet.

VII. Jakarta: Kencana Prenada, 2011.

Rusadi Kantaprawira. Hukum Dan Kekuasaan. Yogyakarta, 1998.

Sadu Wasistiono, MS. M.Irawan Tahir,Si. Prospek Pengembangan Desa. Bandung: CV Fokus Media, 2007.

Sari, Elita Wihajar, Zaid Afif, Fakultas Hukum, Universitas Asahan, and Sumatera Utara. "Jurnal Tectum LPPM Universitas Asahan Edisi Vol. 2, No. 1 November 2020 1" 2, no. 1 (2020): 1-8.

Soekanto, Soerjono. Pengantar 
Penelitian Hukum. Jakarta:

Penerbit Universitas

Indonesia, 2016.

Sunarti, Abdul Gani, Zaid Afif.

"Penyelenggaraan

Pemerintah Kecamatan

Ditinjau Dari Uu No. 23

Tahun 2014 Tentang

Pemerintah Daerah. "Jurnal

Pionir LPPM Universitas

Asahan Vol. 5 N0.4 Juli-

Desember 2019 5, no. 23

(2019): 343-348.

Taliziduhu Ndraha. Dimensi-

Dimensi Pemerintahan Desa.

Jakarta: PT Bumi Aksara, 1991.

Trijono. Lambang Pembangunan Sebagai Perdamaian. Jakarta: Yayasan Obor Indonesia, 2007.

Hasil Wawancara Pada Dengan Bapak Rahmad Hidayat Rambe, S.I.P., Camat Sei Kepayang Barat Pada 23 Nopember 2020.

Peraturan Pemerintah No. 19 Tahun 2008 Tentang Kecamatan.

Peraturan Pemerintah No. 43 Tahun 2014 Tentang Peraturan Pelaksanaan Undang-Undang Nomor 6 Tahun 2014 Tentang Desa. Undang-Undang No. 23 Tahun 2014 Tentang Pemerintahan Daerah. 